\title{
A technical evaluation of raw materials from Western Iraq for ceramic industries: A preliminary study
}

\author{
Ahmad Abed Hamady* \\ Applied Geology Department, College of Science, Anbar University, Iraq
}

\section{ARTICLE INFO}

Article history:

Received 22 January 2017

Accepted 02 May 2017

Keywords:

Western Iraq;

Ceramic industry;

Kaolinitic clays;

Refractories.

\begin{abstract}
A B S T R A C T
Five samples of kaolinite clays and four samples of non- clays were collected from different localities in the Iraqi western desert. These samples representing the operating mines, and some of the identified and inferred clay reserves. The chemical, physical and mineralogical analyses were carried out on these samples. The XRD analysis revealed that the main clay minerals in plastic samples are kaolinite illites However, the non-clay minerals are iron, oxyhydroxides, anatas, quartz, calcite and dolomite. Physical properties including particle size analysis showed that the samples are fine and very fine clays. Plasticity measurements showed that studied samples are super - plastic to non- plastic .Five samples have quick slacking time. Chemical analysis showed that silica, alumina and loss on ignition $\left(1000^{\circ} \mathrm{C}\right)$ are the main constituents. Iron oxides are present in significant and variable proportions whereas the total fluxes are generally low, three of the clay samples are fat and two are lean. Properties after firing were measured on test samples such as linear shrinkage, open porosity, bulk density and water absorption. The behavior of the test tiles during firing was consistent with their chemical composition. The clay samples possess plastic minerals that are suitable for a variety of applications such as whiteware, porcelain \& tiles. The white clays have high alumina content and very low fluxing elements content, which make them good refractory grade clays.
\end{abstract}

\section{Introduction}

Brick and pottery manufacturing are traditional craft known in Iraq since the dawn of history. The flood plain muds of the Mesopotamian plain are the traditional raw materials for the brick industry. The explorations of ceramic clays were first reported in Iraq $1960^{[1]}$. The Ramadi ceramic factory has established a manufacturing tiles and sanitary ware. The factory is currently building up the production level on the basis of materials imported from countries such as Russia and Czech. Whilst this strategy is suitable to the establishment of the factory and the rapid transfer of technology. It is pertinent in the long term to consider the use of raw materials which are nearer to Ramadi, since there could be significant economic advantages ${ }^{[4]}$. The Ramadi ceramic factory has consequently been investigating the types of raw materials in use in the ceramic industries of the Iraq. Stressing that the Ga ara Depression only is the most suitable for sophisticated clay - based ceramic. Investigating and explorations revealed that resources of this commodity in the western desert of Iraq are virtually

* Corresponding author.

E-mail address: drahmed325@yahoo.com unlimited, and large reserves of plastic, semi-plastic, and non-plastic materials are identified (Permo carboniferous and Jurassic age) ${ }^{[2,5]}$. Two of these deposits are currently exploited by open-pit mining (Duekhla clay and Hussainiyat flint clay) and mostly consumed in ceramic, refractory and paper industries. Duekhla clay (Ga" ara Formation-perm carboniferous) was assessed for its suitability in ceramic and refractory industries much more than the other clays such as the works of Zurek and Knapp and many others ${ }^{[2]}$. These studies dealt with assessing the Duekhla clay and non-clays materials for refractories, earthenware, whiteware and porcelain using the various making method (plastic making, semi-dry pressing and slip casting) ${ }^{[6]}$. This work aims to investigate and evaluate the most suitable potential uses of some of the white and colored clays and non - plastic materials of the Jurassic deposits of the western Deseret in terms of their mineralogy, chemistry and physical properties. In addition, the ceramic properties of these clays will be determined over the temperature range $1000^{\circ} \mathrm{C}$ to $1250^{\circ} \mathrm{C}$ in order to check the accuracy of the assessment procedure ${ }^{[2,5]}$. 


\section{Materials and methods}

\section{Clays Materials}

Samples of five clays representative samples were collected from five localities representing operating mines identified and inferred clay reserves (Table 1). They represent white clay $\left(\mathrm{Fe}_{2} \mathrm{O}_{3}<2 \%\right)$ and colored kaolinitic clays $\left(\mathrm{Fe}_{2} \mathrm{O}_{3}>2 \%\right)$. About 5 kilograms were taken from mine faces, boreholes or trenches to represent the whole deposit. The samples were crushed, well mixed and divided into small portions by quartering. The chemical analysis was carried out using the X-ray fluorescence and gravimetric method. Loss on ignition (L.O.I) was calculated after firing to $100^{\circ} \mathrm{C}$. The results are given in (Table 2). The particle size of the clay samples was undertaken using the X-ray serigraph equipment. The results are presented in (Table 3). This test is done to indicate the likely loss of clay during the sieving of the clay slips. It is important in the calculation of quantities and the capacity of the sieving machinery during the slip preparation. The results of the residue test are given in (Table 4). Plasticity index was determined as specified in the ASTM standard D424-59. The results of the plasticity index test are given in (Table 3). This test is undertaken to determine the level of deflocculant needed to produce a satisfactory slip, in this case for spray drying. The results shown in (Table 6) indicate that there is a lower deflocculant demand at higher critical concentration of solids for the samples $(1,2,3$ and 4). This arises because of the larger particle- size of the clay samples. A note should be made of the fact that the clays sample were somewhat difficult to bulge due to the presence of hard clay.

Table (1): Stratigraphic units, reserve and source of clay deposits.

\begin{tabular}{|c|l|l|l|}
\hline $\begin{array}{c}\text { Sample } \\
\text { name }\end{array}$ & Name of clay deposit & Formation & Remark \\
\hline $\mathbf{1}$ & Duekhla clay & Ga ara & Clay mine \\
\hline $\mathbf{2}$ & Duekhla clay coloured & Ga ara & Floor of the Duekhla clay Mine \\
\hline $\mathbf{3}$ & Sufi & Ga ara & Trenches and boreholes \\
\hline $\mathbf{4}$ & Silty soufi & Ga ara & Trenches and boreholes \\
\hline $\mathbf{5}$ & Amij clay & Amij & Trenches only \\
\hline $\mathbf{6}$ & Dolomite & Zur Huran & Rutba Quarry \\
\hline $\mathbf{7}$ & Limestone & Euphrates & Wdi - Gadaf \\
\hline $\mathbf{8}$ & Quartz & Rutba & Rhduma quarry \\
\hline
\end{tabular}

Table (2): Chemical constituents of the studied samples (Clay Materials and non-Clay materials) and their calculated mineralogy

\begin{tabular}{|c|c|c|c|c|c|c|c|c|c|c|}
\hline Sample No & & & & & & & & & & \\
\hline $\begin{array}{c}\text { Material } \\
\text { component }\end{array}$ & Clay & Clay & Clay & $\begin{array}{c}\mathbf{4} \\
\text { Clay }\end{array}$ & Clay & Clay & Clay & $\begin{array}{c}\text { d } \\
\text { Dolomite }\end{array}$ & $\begin{array}{c}9 \\
\text { Limestone }\end{array}$ & $\begin{array}{c}10 \\
\text { Quartz }\end{array}$ \\
\hline $\mathrm{SiO}_{2}$ & 48.1 & 53.9 & 58.70 & 65.40 & 45.50 & 47.40 & 45.40 & $1-50$ & 8.66 & 9805 \\
\hline $\mathbf{A l}_{2} \mathbf{O}_{3}$ & 34.7 & 25.0 & 25.4 & 20.70 & 24.40 & 32.10 & 25.10 & 1.25 & 7.85 & 0.25 \\
\hline $\mathrm{Fe}_{2} \mathrm{O}_{3}$ & 1.05 & 1.11 & 2.2 & 2.15 & 7.85 & 9.20 & 9.11 & 0.05 & 2.33 & 0.16 \\
\hline $\mathrm{TiO}_{2}$ & 1.23 & 1.28 & 1.11 & 1.33 & 1.33 & 1.73 & 1.67 & 0.05 & 0.60 & n.a \\
\hline $\mathrm{Na}_{2} \mathrm{O}$ & 0.29 & 0.71 & 0.38 & 0.28 & 0.78 & 0.72 & 1.39 & n.a & 1.04 & n.a \\
\hline $\mathbf{K}_{2} \mathbf{O}$ & 0.64 & 0.68 & 1.42 & 0.98 & 1.12 & 0.55 & 0.40 & 0.23 & 0.90 & n.a \\
\hline $\mathrm{CaO}$ & 0.20 & 0.14 & 0.46 & 0.35 & 5.65 & 0.29 & 0.30 & 1.85 & 43.80 & 0.09 \\
\hline MgO & 0.39 & 0.39 & 0.90 & 0.66 & 1.68 & 1.61 & 0.95 & 1.20 & 12.80 & n.a \\
\hline L.O.I & 13.60 & 10.80 & 10.11 & 7.70 & 12.00 & 14.60 & 14.40 & 45.19 & 25.33 & 0.22 \\
\hline Kaolinite & 84.9 & 60.30 & 54.90 & 48.10 & 38.20 & 38.40 & 54.00 & -- & --- & -- \\
\hline Illite & 4.1 & 5.50 & 13.88 & 9.40 & 11.17 & 3.40 & 1.40 & ----- & --- & --- \\
\hline smectite & - & - & - & - & 32.50 & 38.00 & 18.40 & --- & --- & -- \\
\hline Quartz & 7.02 & 22.4 & 26.1 & 38.10 & 3.20 & 6.1 & 9.60 & 6.11 & 6.11 & 99.00 \\
\hline Geothite & - & 6.1 & 1.80 & 1.40 & 5.50 & 7.10 & 8.80 & ----- & --- & --- \\
\hline Anatas & 1.4 & 1.4 & 0.20 & 1.30 & 1.40 & 1.76 & 1.55 & --- & --- & --- \\
\hline Halite & 0.4 & 0.80 & 0.70 & 0.68 & .60 & 1.40 & 2.40 & --- & --- & --- \\
\hline
\end{tabular}

n.a= not analyzed 
Table (3): The percentages of (clay materials) contained between 2 size fractions, below 2 microns and 1 microns, size class, plasticity index and nature of slaking.

\begin{tabular}{|c|c|c|c|c|c|c|c|c|c|}
\hline $\begin{array}{c}\text { Sample } \\
\text { no. }\end{array}$ & $\mathbf{>} \mathbf{2 0 u m}$ & $\mathbf{1 0 - 2 0}$ & $\mathbf{5 - 1 0}$ & $\mathbf{2 - 5}$ & $\mathbf{2}$ & $\mathbf{<}$ & Size class & $\begin{array}{c}\text { Plasticity } \\
\text { index }\end{array}$ & $\begin{array}{c}\text { Nature of } \\
\text { slakin }\end{array}$ \\
\hline $\mathbf{1}$ & 5.22 & 1.97 & 2.88 & 6.43 & 79.98 & 69.00 & Very fine & 32 & Quick \\
\hline $\mathbf{2}$ & 2.96 & 1.88 & 2.45 & 8.91 & 82.85 & 74.00 & Very fine & 30 & slow \\
\hline $\mathbf{2}$ & 4.88 & 3.97 & 8.21 & 14.43 & 68.33 & 56.33 & fine & 24 & Quick \\
\hline $\mathbf{4}$ & 15.34 & 11.00 & 10.23 & 11.11 & 47.88 & 38.24 & coarse & 16 & Quick \\
\hline $\mathbf{5}$ & 6.77 & 4.23 & 5.12 & 8.54 & 48.43 & 76.11 & Fine & 23 & Very slow \\
\hline $\mathbf{6}$ & 19.47 & 2.95 & 3.21 & 5.00 & 67.11 & 64.22 & coarse & 25 & moderate \\
\hline $\mathbf{7}$ & 9.35 & 8.65 & 4.78 & 4.33 & 70.22 & 73.87 & Fine & 13 & Slow \\
\hline $\mathbf{8}$ & 0.11 & 0.13 & 1.33 & 1.66 & 58.55 & 81.25 & Very fine & 11 & Quick \\
\hline $\mathbf{9}$ & 0.67 & 1.77 & 7.88 & 14.00 & 78.70 & 66.94 & Very fine & 15 & Quick \\
\hline
\end{tabular}

Table (4): Residues of clay samples.

\begin{tabular}{|c|c|c|}
\hline \multirow{2}{*}{ Sample } & \multicolumn{2}{|c|}{ Residues } \\
\cline { 2 - 3 } & On 72p s mesh & On 120 s mesh \\
\hline $\mathbf{1}$ & 0.38 & 0.05 \\
\hline $\mathbf{2}$ & 0.56 & 0.05 \\
\hline $\mathbf{3}$ & 2.30 & 0.72 \\
\hline $\mathbf{4}$ & 0.10 & 0.33 \\
\hline $\mathbf{5}$ & 7.60 & 0.33 \\
\hline
\end{tabular}

Table (5): Particle size analyses of clays.

\begin{tabular}{|c|c|c|c|c|c|c|}
\hline \multirow{2}{*}{ Sample } & \multicolumn{7}{|c|}{ Percentage less than given diameter (microns) } \\
\cline { 2 - 7 } & 20 & 10 & 5 & 2 & 1 & 0.5 \\
\hline $\mathbf{1}$ & 95 & 90 & 78 & 55 & 41 & 25 \\
\hline $\mathbf{2}$ & 95 & 90 & 79 & 55 & 37 & 17 \\
\hline $\mathbf{3}$ & 94 & 89 & 78 & 55 & 42 & 32 \\
\hline $\mathbf{4}$ & 97 & -- & -- & 70 & -- & 44 \\
\hline $\mathbf{5}$ & 97 & -- & -- & 81 & -- & 53 \\
\hline
\end{tabular}

Table (6): Rheology of clay samples.

\begin{tabular}{|c|c|c|}
\hline Sample & $\begin{array}{c}\text { Deflocculant demand (\%) } \\
\mathbf{1 : 1} \text { silicate ash }\end{array}$ & $\begin{array}{c}\text { Critical Solids } \\
\text { Conc. (\%) }\end{array}$ \\
\hline $\mathbf{1}$ & 0.2 & 67.2 \\
\hline $\mathbf{2}$ & 0.2 & 68.8 \\
\hline $\mathbf{3}$ & 0.3 & 64.3 \\
\hline $\mathbf{4}$ & 0.8 & 59.0 \\
\hline $\mathbf{5}$ & 0.5 & 64.0 \\
\hline
\end{tabular}

Sample (4) was the worst in this respect, but clay grinding would alleviate any problem. The modulus of rupture of clay means assessing the strength of the clay, and is useful in predicting whether the clay will be easy to handle without damage. Strength is essentially a function of the packing of the particles in the clay, and depends on the moisture content. The strength is a maximum when the clay is perfectly dry. The samples are usually prepared by bringing the clay into its plastic form, extruding it as rods, drying, and then breaking under 3-point loading. The results obtained for clays (1, 2, 3, 4 and 5) are given in (Table 10). The irreversible thermal expansion of clay can be used to complement the information already obtained from the other tests such as thermal behavior at $1000^{\circ} \mathrm{C}$ to $1250^{\circ} \mathrm{C}$. For this purpose, test tiles $(8 \times 4 \times 1 \mathrm{~cm})$ were prepared by semi-dry molding under $250 \mathrm{~kg} / \mathrm{cm}^{2}$ pressure, oven dried $\left(105^{\circ} \mathrm{C}\right.$ for 24 hours) and fired to $1000,1050,1150,1200$ and $1250^{\circ} \mathrm{C}$ (temperature rise 50/hour) for 2 hours soaking time.

\section{Non-clay materials}

Samples of quartz, limestone, and dolomite were collected from three localities representing operating mines (Table 1). The evaluation of the non - plastic has been on the basis of the chemical analysis. The chemical 
analysis, by X.R.F. is shown in (Table 2), along with that for good quartz materials as used in ceramic industry. So that the quartz sample is good. There are quite marked differences between chemical analyses of the dolomite sample and typical dolomite analysis as shown in (Table 8). The main differences arises in the $\mathrm{CaO}$ and $\mathrm{MgO}$ contents, this indicates that the dolomite sample contains a large proportion of limestone $\left(\mathrm{CaCO}_{3}\right)$. Also, of course, dolomite since it theoretically contains equimolecular amounts of calcium and magnesium carbonates should contain no silica. A calculation shows this dolomitic material to consist mainly of $\left(73.40\right.$ wt. $\% \quad(\mathrm{Ca}, \mathrm{Mg})\left(\mathrm{CO}_{3}\right)_{2}$ dolomite mineral), Limestone (23.98 wt.\% $\quad \mathrm{CaCO}_{3}$-calcite mineral) and Quartz (1.56 wt.\%). The fact that the existence of limestone and quartz as impurities in the dolomite does not cause rejection of this material. Both of these impurities can be tolerated if due allowance is made in the final recipe. Table 8 shows marked difference between the analysis of the sample limestone, and that of good ceramic grade. From the analytical data the main components of the limestone material are Limestone (78.44\%), calcium phosphate (11.02 wt.\%), Magnesium carbonate (4.25 wt.\%) and Quartz (6.11 wt.\%). The most serious impurity is the calcium phosphate, which can in certain circumstances cause problems, due to discoloration during firing.

\section{Results and Discussion:}

The clay samples have various colors. The gray color is attributed to the organic matter (as plant debris) whereas the yellow, reddish brown and variegated colors are attributed to the presence of iron (ferrous and ferric) oxides and hydroxides coats around the clay particles. XRD analysis of clay samples revealed that the major clay mineral present is kaolinite with variable amount of illite and mixed- layer (illite - smectite) (Figs. 1, 2, 3 and 4). The other main admixtures present are quartz, iron oxyhydroxides (mostly goethite), anatase and organic matter.

Table (7): Linear shrinkage of fired bodies.

\begin{tabular}{|c|c|c|c|c|c|}
\hline Sample & $\mathbf{1 0 0 0}^{\mathbf{}} \mathbf{C}$ & $\mathbf{1 0 5 0}^{\mathbf{}} \mathbf{C}$ & $\mathbf{1 1 0 0}^{\mathbf{}} \mathbf{C}$ & $\mathbf{1 1 5 0}^{\mathbf{}} \mathbf{C}$ & $\mathbf{1 2 5 0}^{\mathbf{}} \mathbf{C}$ \\
\hline $\mathbf{1}$ & 1.11 & 1.15 & 1.18 & 1.22 & 1.34 \\
\hline $\mathbf{2}$ & 0.40 & 0.50 & 0.90 & 1.10 & 1.20 \\
\hline $\mathbf{3}$ & 0.16 & 0.38 & 0.27 & 1.13 & 1.25 \\
\hline $\mathbf{4}$ & 0.12 & 0.88 & 1.97 & 2.95 & 2.4 \\
\hline $\mathbf{5}$ & 0.22 & 0.38 & 0.40 & 0.44 & 2.20 \\
\hline
\end{tabular}

Table (8): Water absorption of fired bodies.

\begin{tabular}{|c|c|c|c|c|c|}
\hline Sample & $\mathbf{1 0 0 0}^{\mathbf{}} \mathbf{C}$ & $\mathbf{1 0 5 0}^{\mathbf{}} \mathbf{C}$ & $\mathbf{1 1 0 0}^{\mathbf{C}}$ & $\mathbf{1 1 5 0}^{\mathbf{}} \mathbf{C}$ & $\mathbf{1 2 5 0}^{\mathbf{}} \mathbf{C}$ \\
\hline $\mathbf{1}$ & 28.5 & 26.1 & 25 & 21.4 & 20.0 \\
\hline $\mathbf{2}$ & 28.7 & 28.0 & 27 & 25.1 & 22.0 \\
\hline $\mathbf{3}$ & 20.2 & 20.0 & 20 & 16.5 & 15.1 \\
\hline $\mathbf{4}$ & 20.0 & 18.8 & 15.5 & 13.20 & 11.3 \\
\hline $\mathbf{5}$ & 25.5 & 18.9 & 17.70 & 14.0 & 10.4 \\
\hline
\end{tabular}

Table (9): Apparent porosity of fired bodies.

\begin{tabular}{|c|c|c|c|c|c|}
\hline Sample & $\mathbf{1 0 0 0}^{\mathbf{C}} \mathbf{C}$ & $\mathbf{1 0 5 0}^{\mathbf{C}} \mathbf{C}$ & $\mathbf{1 1 0 0}^{\mathbf{C}}$ & $\mathbf{1 1 5 0}^{\mathbf{C}}$ & $\mathbf{1 2 5 0}^{\mathbf{C}} \mathbf{C}$ \\
\hline $\mathbf{1}$ & 38.10 & 36.50 & 33.5 & 34.3 & 33.20 \\
\hline $\mathbf{2}$ & 41.50 & 40.0 & 40.30 & 35.9 & 30.15 \\
\hline $\mathbf{3}$ & 32.30 & 31.30 & 31.5 & 30.9 & 27.50 \\
\hline $\mathbf{4}$ & 34.15 & 34.20 & 33.5 & 31.20 & 30.90 \\
\hline $\mathbf{5}$ & 33.20 & 33.0 & 33.0 & 26.6 & 19.70 \\
\hline
\end{tabular}

Table (10): Density and color of fired samples.

\begin{tabular}{|c|c|c|c|c|c|c|}
\hline \multirow{2}{*}{ Sample } & \multicolumn{5}{|c|}{ Bulk Density at $\left(\mathbf{C}^{\mathbf{0}}\right)$} & \multirow{2}{*}{ Color at $1200^{\circ} \mathrm{C}$} \\
\hline & 1000 & 1050 & 1100 & 1150 & 1250 & \\
\hline 1 & 1.75 & 1.87 & 2.00 & 2.08 & 2.11 & 67.9 \\
\hline 2 & 1.63 & 1.82 & 2.00 & 2.11 & 2.13 & 67.6 \\
\hline 3 & 1.73 & 1.88 & 2.04 & 2.11 & 2.16 & 66.7 \\
\hline 4 & 1.67 & 1.88 & 2.06 & 2.13 & 2.16 & 66.9 \\
\hline 5 & 1.88 & 1.89 & 2.07 & 2.14 & 2.19 & 66.9 \\
\hline
\end{tabular}




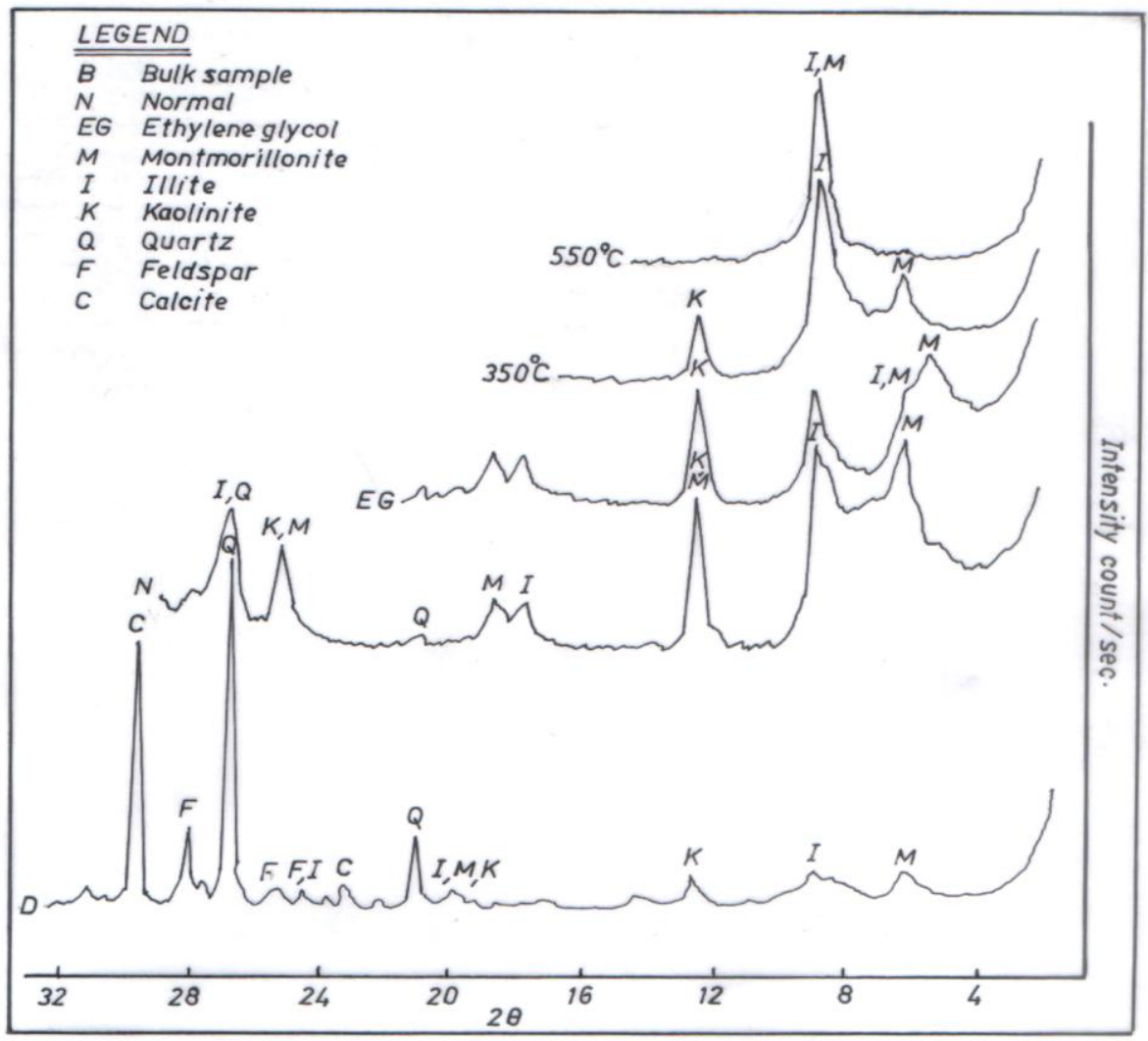

Fig (1): XRD diffractograms of sample 1.

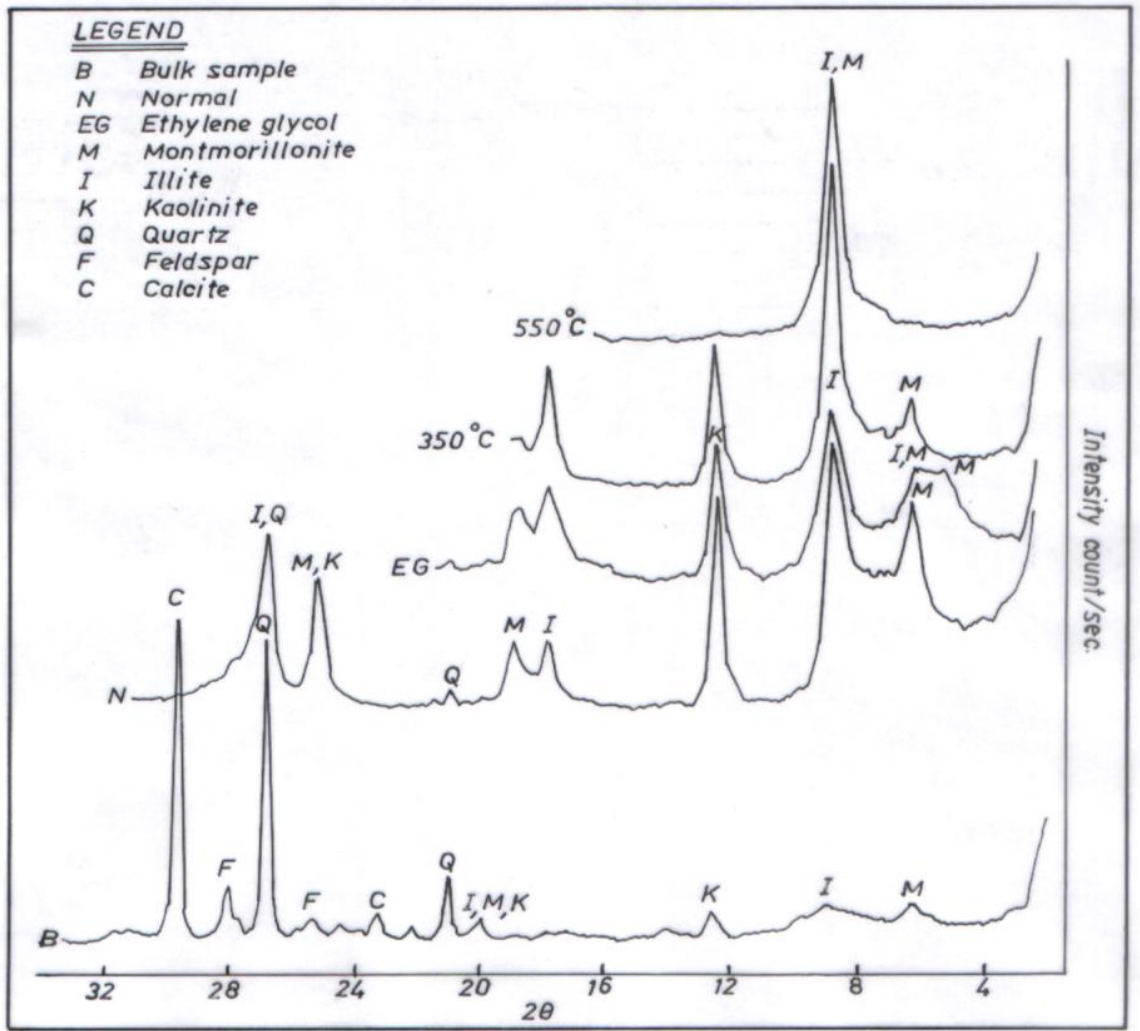

Fig (2): XRD diffractograms of sample 2. 


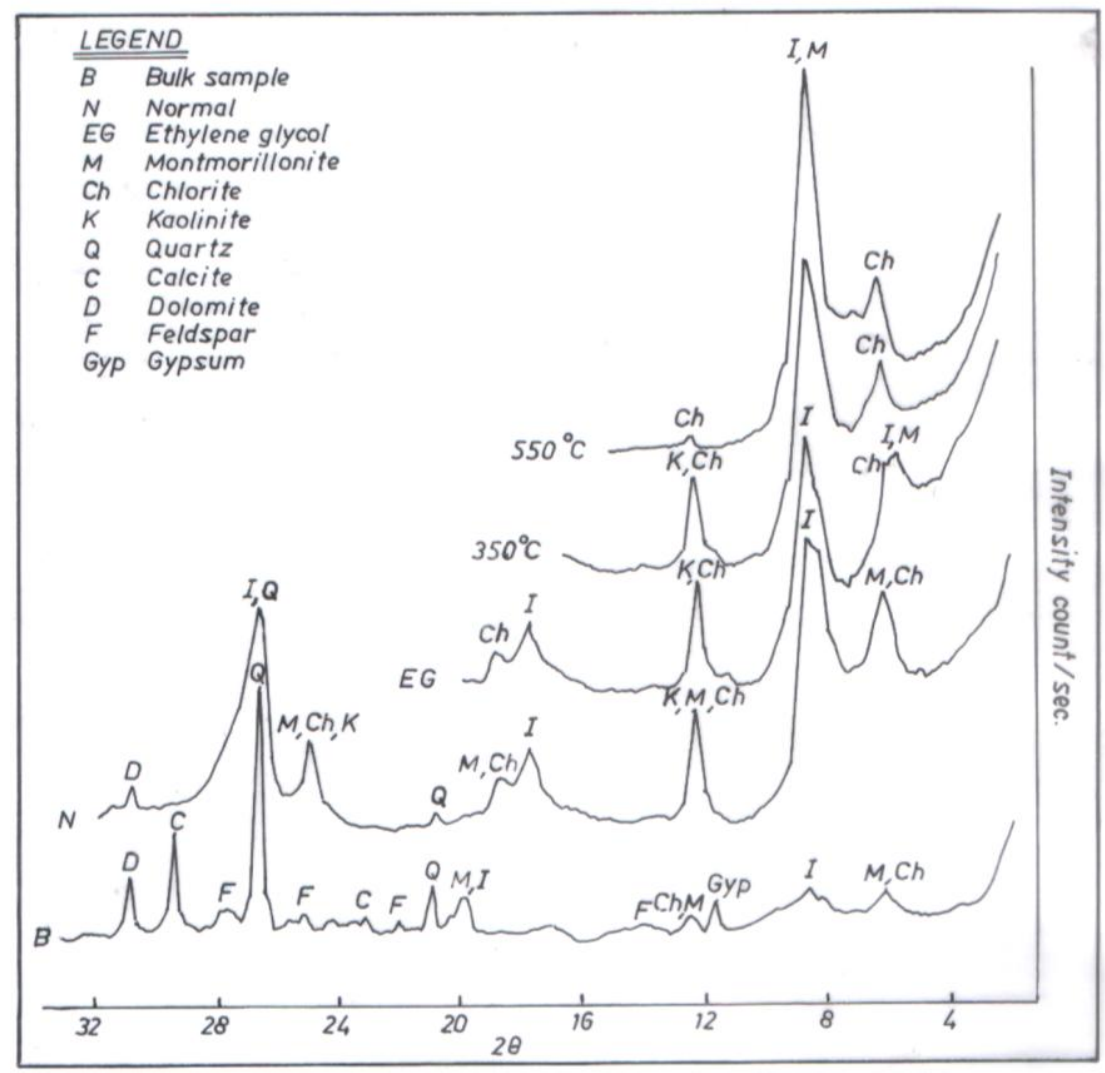

Fig (3): DTA curves of the studied clays (sample 3).

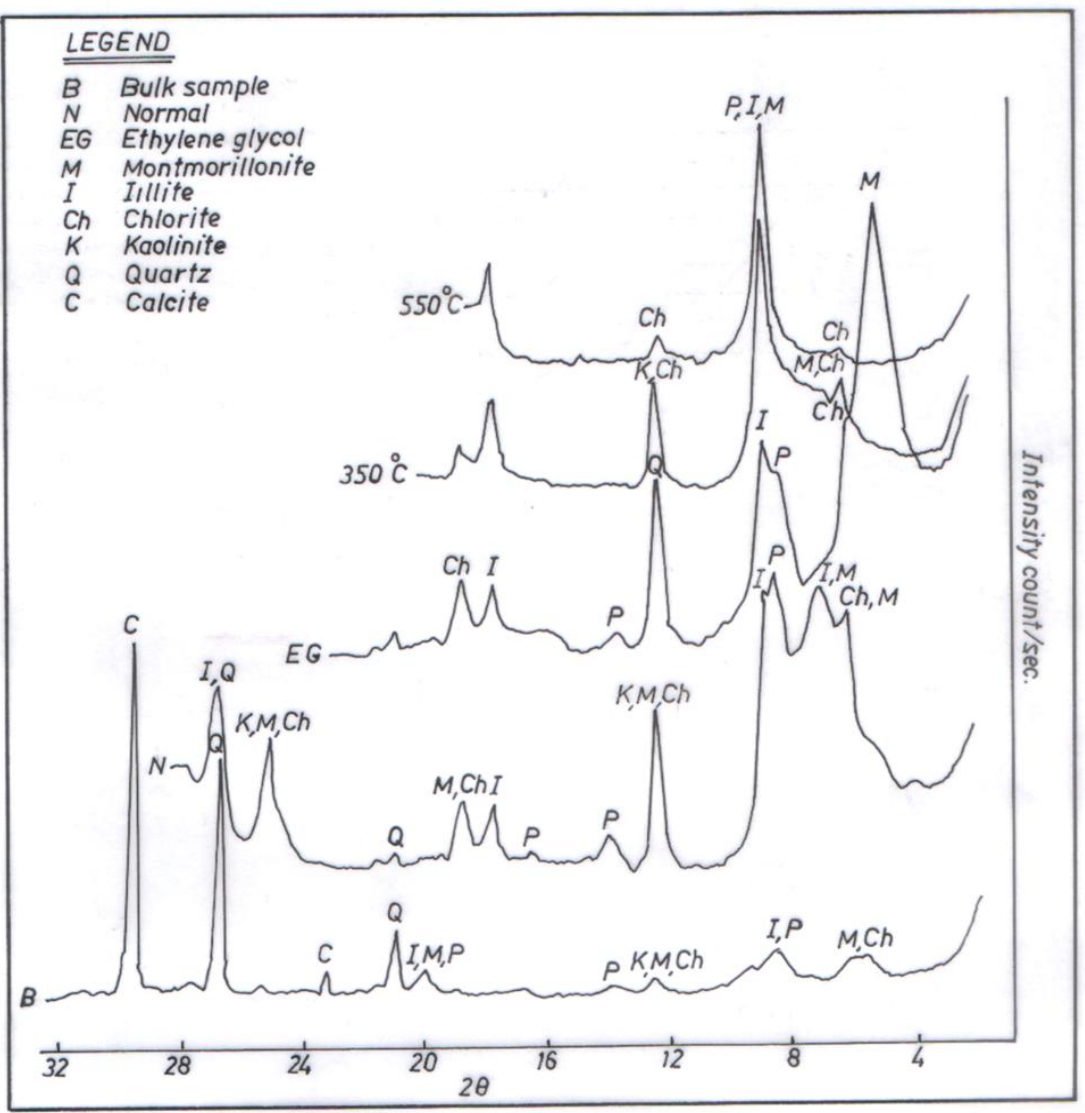

Fig (4): X-ray spectra inferred samples 4 and 5. 
DTA analysis supports the XRD results as the shape of their curves are not greatly affected by the other minor components and represent a typical kaolinite curves (Fig. 3). Four major peaks can be recognized, the first peak is endothermic and lies between $90-150^{\circ} \mathrm{C}$ resulting from the removal of the non-constitutional water in the kaolinites and the loss of a water molecule in the mixedlayer illite-smectite, the second peak is endothermic and lies between $320-410^{\circ} \mathrm{C}$ representing a combination of peaks resulting from the loss of structural water of mixed-layer illite-smectite and illite $\left(320-335^{\circ} \mathrm{C}\right)$ and dehydroxylation of goethite $\left(335-410^{\circ} \mathrm{C}\right)$, the third peak is endodermaic and is the most prominent occurring at the temperature range between $570-630^{\circ} \mathrm{C}$ which corresponds to the explution of water from the kaolinite lattice, the fourth peak is exothermic and lies between $940^{\circ} \mathrm{C}$ and $1000^{\circ} \mathrm{C}$ resulting from the formation of mullite, spinel and cristobalite. Chemical composition of the studied samples is presented in (Table 2). The main constituents of the investigated clays are $\mathrm{SiO}_{2}, \mathrm{Al}_{2} \mathrm{O}_{3}$ and (L.O.I) significant amount of $\mathrm{Fe}_{2} \mathrm{O}_{3}$ is recorded in the samples ranging from 0.91-9.70 whereas titania is approximately constant ranging from 1.12- 2.34 and are usually higher in the Amij clays than in the $\mathrm{Ga}$ "ara and Amij clays. The total alkalis $\left(\mathrm{Na}_{2} \mathrm{O}, \mathrm{K}_{2} \mathrm{O}, \mathrm{CaO}\right.$ and $\mathrm{MgO}$ ) which behave as fluxes during firing are generally in the Ga" ara and Amij clays (0.86-3.17) but are considerably higher in the Amij clays (9.18). The Alumina content of the investigated clays range from (20.8-3504), On the basis of Alumina content ,Clays can be classified into fat $\left(30 \% \mathrm{Al}_{2} \mathrm{O}_{3}\right)$ moderately fat (25$\left.30 \% \quad \mathrm{Al}_{2} \mathrm{O}_{3}\right)$ and lean (20-25\% $\left.\quad \mathrm{Al}_{2} \mathrm{O}_{3}\right)$. Accordingly three samples are fat (samples1, 7 and 8), one sample is moderately fat (sample 3) and five samples are lean (samples 2, 3, 4 and 5). On the basis of chemical analysis (Table 2 and Fig. 6) three samples only (1, 3 and 5) seem suitable for refractories as they are fat have low total alkalis content whereas all studied samples seem suitable for ceramic in general. Particle size analysis (Table 3) showed that three samples are very fine clays (samples 1, 2 and 5), three samples are fine clays (samples 1, 3 and 5) and two samples are coarse clays (samples 4 and 5). This scheme of clay classification according to particle size was proposed by Mustafa ${ }^{[13]}$. Plasticity Index (P.I) values ranged from 11 to 30 (Table 3) Ga" ara clays showed higher plasticity than Amij clays. Clays for ceramic industries were classified based on plasticity index by Budnikov ${ }^{[8]}$ into five groups. The Ga ara supper - plastic (samples 1 and 2) and medium plastic samples (3 and 4). The Ga"ara clays and Amij clays are medium plastic except sample 5 which is moderately plastic and samples 6,7 and 8 which are non-plastic. Plasticity values showed wide range of variation and are intimately related to particle size distribution and mineralogy. The finer the particle size and the higher content of phyllosilicate the higher values of plasticity index such as sample 1. Plasticity data were plotted on clay workability chart (unpublished data of the British Geological survey) and showed that samples 1, 2, 3, 4 and 5 have moderate shrinkage on drying and thus need to be mixed with non-plastic materials to reduce their plasticity. Non- fired bodies to be formed by plastic methods from sample 5 poorer cohesion and weaker only would produce body and needs addition of some plasticizer. Along with comparative values for the clays now being used. The values obtained for the sample clays are low, and are intermediate between those of a processed china clay and a ball-clay ${ }^{[1]}$. The explanation is that the clayey samples contain rather less kaolin, which is of a coarse grain-size, and there is a lack of organic material to act as a binder. The evidence presented in the clays indicates that the clay samples 1, 2, 3 and 4, should be considered as components of a wall-tile body composition. Clay sample 5 is not included because of the variety of other materials in it, and the high level of quartz. Clay sample 5 is excluded because of very high residue. Of the clay, 1 with either 2 or 3 would form the basis of some useful development work.

Nature of slaking is tested in order to investigate the binding strength of the clay particles and the degree of consolidation of the clay mass (Table 3). Ga"ara and Amij clay (sample 5) disintegrate within 2-4 minutes after their immersion in water whereas the Amij clay (sample 5) requires longer time for their samples to disintegrate regarding the firing behavior, the linear shrinkage, bulk density, open porosity and water absorption results were lotted as firing diagram (Figs. 5, 6, 7 and 8). It seems that the chemical composition of the raw clays control the shape of these curves. The results are presented in (Tables $7,8,9$ and 10). The clays differ very little from each other at the applied firing temperatures. However, none of them has been fired to their point of maximum bulk density. This supports the point made above that, these clays are more refractory than the ones in current use. The water absorption values at $1200^{\circ} \mathrm{C}$ show that these clay samples have reached maximum density at these temperatures. Since the color measurements were made on samples, which were not dense, however, they do indicate that the degree of discoloration can probably be controlled. In general clays with little impurities sustain higher temperatures and hence physical properties of the test tiles level off at temperatures as higher as $1200^{\circ} \mathrm{C}$.

On the other hand, physical properties of clays containing high impurities, such as alkalis and iron oxides, level off at temperatures ranging from $1050^{\circ} \mathrm{C}$ to $1100^{\circ} \mathrm{C}$ depending on the contents of their impurities. sample 4 showed different firing behavior (Figs. 7 and 8) as its linear shrinkage and bulk density show gradual and very slight increase whereas its open porosity and water absorption decrease with steeper gradient. This relationship can be attributed to the presence of high amount of quartz (Table 2) so that, the increasingly 1050-1100 degrees be liquid glass phase and increasing sintering process to reduce water absorption. Based on the available data the quartz and dolomite would seem to be directly accepted as materials to be used in trials to develop a wall-tile. There is doubt regarding limestone because of the high level of calcium phosphate. This impurity could cause problems in the firing of the body. 


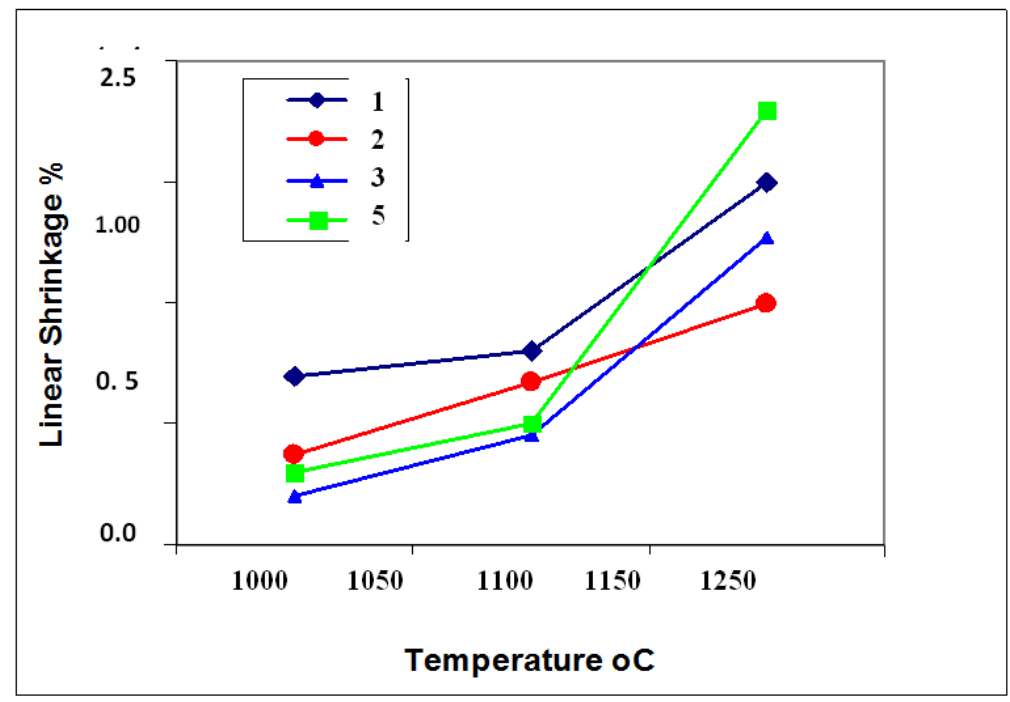

Fig (5): The Relationship between the linear Shrinkage and firing temperatures.

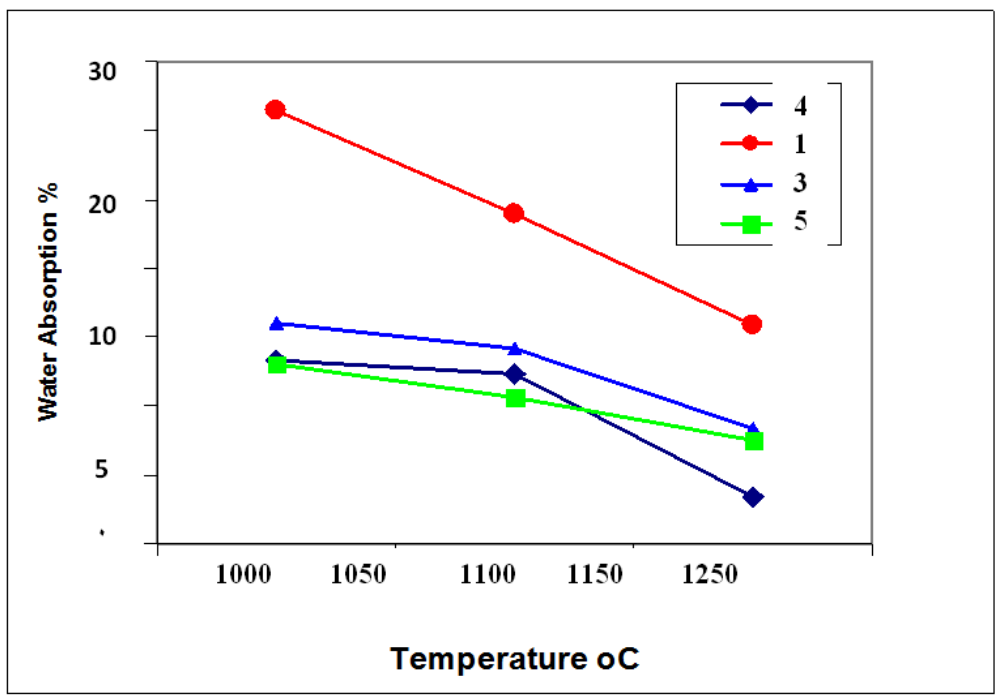

Fig (6): The Relationship between the water absorption and firing temperatures.

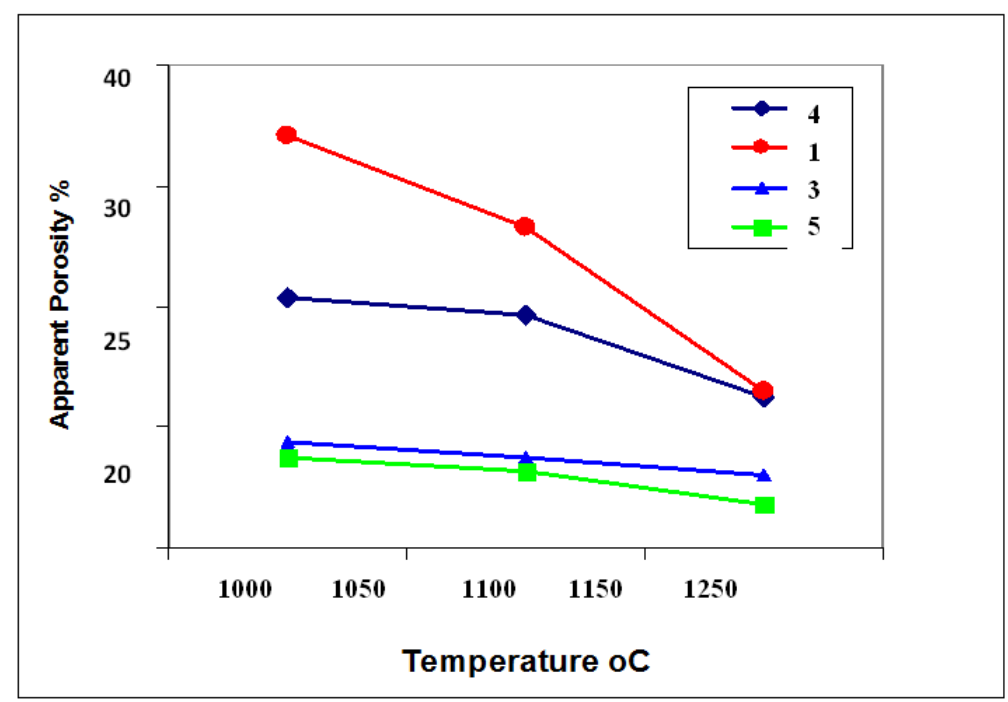

Fig (7): The Relationship between apparent porosity and firing temperatures. 


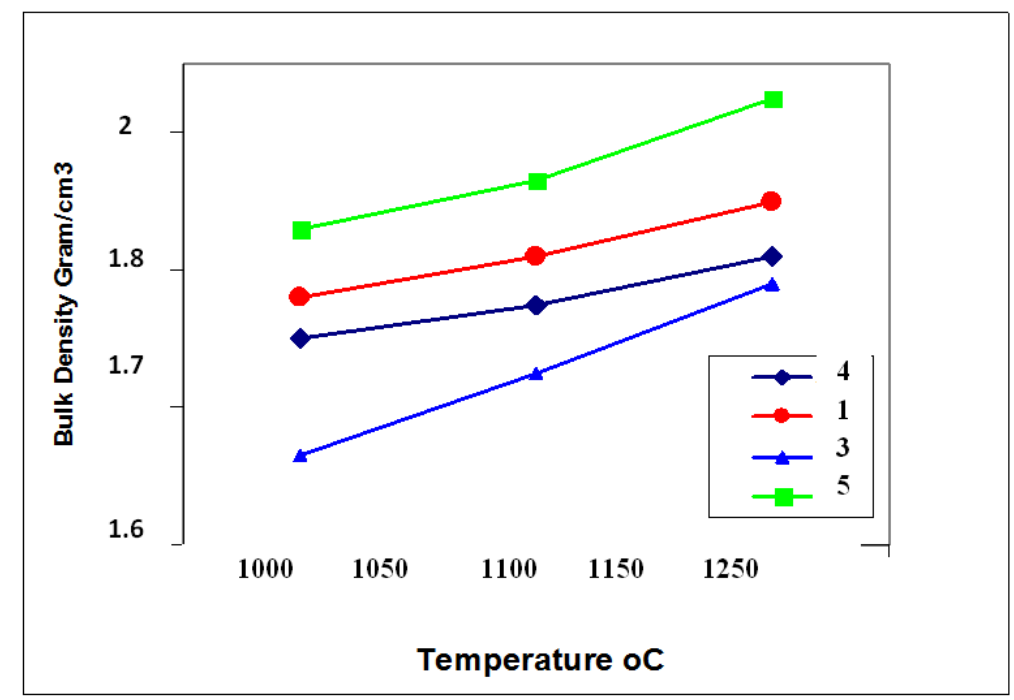

Fig (8): The Relationship between bulk density and firing temperatures.

\section{Conclusions}

Three of the studied clays only are suitable for refractories namely sample 1,3 and 5 as they are fat and have low fluxing compounds. Addition of precalcined kaolin (grog) would undoubtedly improve refractoriness. The same samples seem also suitable for the production of sophisticated ceramics such as whitewater, porcelain, electro porcelain and chemical stoneware, as they fire to slightly off-white color and sustain high temperature. The addition of silica sand and fluxing materials are required in order to improve plasticity sample (1) and produce sufficient amount of glassy phase. Sample (8) is non-plastic and therefore needs the addition of plasticizer for plastic making or semi-dry pressing. Sample (3) and (4) are suitable for stoneware beside the abovementioned samples, whereas Samples (2), (3) and (4) are suitable for the production of red bodies such as roof tiles. Sample (5) is comparatively impure and is suitable for the production of roof tiles, unglazed pipes and structural bricks.

\section{Acknowledgment}

The author is indebted to the state Enterprise of the Geological survey and Mining for carrying out the chemical analysis and the physical properties after firing.

\section{References}

1) Zurek, V. and Knapp, T. (1960). Ceramic material deposits, Telafif. Unpub. Report 380, GEOSERV Library, Baghdad, 43 pp.

2) Tamar-Agha, M. V. (1997). Assessment of some kaolinitic clays from western Iraq for ceramic and refractory industries. Jordan conference on mining, :316-333.

3) Al-Azzawi, N. Y. and Aly, A. A. (1983). Suitability of Iraqi raw materials in processing of electric porcelain industries. Unpub. Report 1312, GEOSURV library, Baghdad, 45 pp.
4) Al- Kasiyi, H. B. W. (1988). The Iraqi soils and their suitability in ceramic. Unpub. M.Sc. Thesis, Univ. of Baghdad, 124 pp. (in Arabic)

5) Al-kaisyi, F. A. S. (1989). Suitability of Iraqi clays to slip casting. Unpub. M.Sc. Thesis, Univ. of Baghdad, 216 pp. (in Arabic)

6) Al-Khafaji, S. R. (1994). Mineralogy and geochemistry of Hussainiyat clays and their suitability in ceramic industries. Unpub. M.Sc. Thesis, Univ. of Baghdad, 119 pp. (in Arabic)

7) Al-Mashaykhi, H. K. (1991). Assessment of some Iraqi raw materials and their suitability in manufacturing of stoneware ceramics. Unpub. M.Sc. Thesis, Univ. of Baghdad, 220 pp. (in Arabic)

8) Budnikove, P. P. (1964). The technology of ceramic and refractories. The M.I.T. Press, Cambridge, 647p.

9) Fabbri, B. and Fiori, C. (1985). Clays and complementary raw materials for stoneware tiles. Miner. petrogr. Acta, 29-A:545.

10) Ganim, F. A. K. (1996). Assessment of some Iraqi raw materials and their suitability in the manufacturing of kiln shelves. Unpub. M.Sc. Thesis, Univ. of Baghdad, 153 pp. (in Arabic).

11) Hamadi, A. A. (2007). Assessment and utilities of Paleogene clays in North Estren Iraq for ceramic. Unpub. Thesis, Univ. of Baghdad, 145 pp. (in Arabic)

12) Hamadi, A. A. (2002). Utilization of Iraqi raw materials for the manufacturing of fast - single firing ceramic tiles, Unpub. M.Sc. Thesis, Univ. of Baghdad, 124 pp. (in Arabic).

13) Mustafa, G. M. M. (1981). Assessment of Kaolinitic clays from the Al- $\mathrm{Ga}$ ara area of western Iraq. Unpub. M.Sc. Thesis, Univ.of Hull, U.K., 86 pp. 